ISBN 978-93-84468-83-5

International Conference on Studies in Arts, Law and Education

(ICALE-2016)

Singapore Dec. 5-6, 2016

\title{
Compulsory License in Biodiversity Based Patent: Public Health Concern and Benefit Sharing for Developing Countries
}

\author{
Dr.Ranti Fauza Mayana, SH. ${ }^{1}$, and Tisni Santika, $\mathrm{SH}, \mathrm{MH} .^{2}$ \\ ${ }^{1}$ Law Faculty of Padjadjaran University, Indonesia. (email: ranti_fauza@yahoo.com) \\ ${ }^{2}$ Law Faculty of Pasundan University, Indonesia. (email: tisnisantika@ yahoo.co.id)
}

\begin{abstract}
It is certainly true that when it comes to high-quality medicines,-most of which are produced by international pharmaceutical companies - people have to pay premium prices. The prices are unaffordable for most of society in developing and under developed countries. With some $80 \%$ of the world's biological diversity lying in the tropical and sub tropical regions of the south (Velasquez G. and Boulet P, 1999), accompanied by the fact that $56 \%$ of the top 150 prescribed drugs in the United State of America are based on chemicals derived from plants (Inter Press Service, 1998), and the existence of a world market for herbal medicine estimated at USD 43 billion with annual growth rate of between $5 \%$ to $15 \%$ (The Inter - Regional Workshop on Intellectual Property Rights, 2000), the potential of biological diversity to secure public health are enormous. On the other hands the massive economic rewards for pharmaceutical industry make it such a high temptation for pharmaceutical companies to commit biodiversity prospecting and ended up with acts of biodiversity piracy seeking exclusive monopoly over these resources and knowledge using patent - based intellectual property rights as the tool to set up a high standard price that resulting the potential to harm the public health and access to medicine which is a growing problem in developing countries and under developed countries due to the fact that medicines are unavailable, inaccessible or unaffordable for those who need them most. The protection of public health is one of the most pressing issues in developing countries because a large part of the world population still lacks access to essential drugs.
\end{abstract}

Keywords----Compulsory License, Patent, Biodiversity Piracy, Public Health, Fair and equitable benefit sharing

\section{Introduction}

\section{Statement of the Problems}

The conceptual framework of intellectual property rights cannot be apart from economic activity, including international trade. One of the most effective ways to survive in international market is by owning monopoly of technology and innovation using patent. Patent granted based on "novelty", "inventive step" and "industrial applicability" (Vaper, 1999). Patent grants exclusive rights and available for the development of products and processes. Inventor is permitted to transfer his exclusive rights based on agreement with another party. Another exclusive right granted by patent is that the inventor and patent holder are able to forbid another party to produce the same product based on their invention. These exclusive rights have a strong tendency to create monopoly. The inventor or patent rights holder has exclusive rights to determine the price of the product and to decide a 
certain amount of production to limit the availability of products. These patent - based monopolies sadly occurred in medicine sector and create a serious threat to public health security in developing countries. The ultimate irony lies in the fact that developing countries are rich of biological diversity have been the main sources for pharmaceutical companies to conduct biodiversity prospection in order to "invent" new medicine products derived from their genetic resources using their indigenous community's knowledge.

There are common misunderstanding and misinterpretation that compulsory license can only be conduct by the government to produce the generic version of essential patented medicines such as HIV/AIDS, Tuberculosis, Hepatitis, Malaria without the authorization of the rights holder and practically, compulsory license only allowed to be performed by government in certain situations with few requirements like health national emergency, public use and in non commercial grounds. Considering the biodiversity and traditional knowledge of developing countries are used and - in many occasions exploited - in biodiversity prospection resulting new invention of medicines but on the other hand the invention of new medicines and patent technologies have less impact of securing public health, moreover create a patent monopoly that narrowing the access to medicines and create an unbearable harm to public health in developing countries, the two most important statements of the problems in this paper are:

1. How the patent regulation in developing countries should be designed to serve the interest of society and responsive to public health and, in particular to the needs of the poor.

2. Within the limit imposed by international obligations, compulsory license policy should be acknowledged as the rights and duty of the state and project as one of the implementation of fair and equitable benefit sharing in Biodiversity - based Patents

\section{Objectives}

1. To analyze the sovereignty of the state in implementing patent regulation to serve the interest of society concerning national public health security

2. To identify the possibility of implementing automatic compulsory license as the form of fair and equitable benefit sharing for biodiversity based-patent to ensure the security of public health in origin country

\section{Significance of the Study}

This research expected to be the reference for interested parties and institutions related to the regulation making process of patent and national public health policy to create the patent regulation that serve public interest, enlarge the access to medicines and can be the tool of socio economic upgrading, also can be a hint for scholars and academic research considering intellectual property rights, patent law and public health.

\section{Theoritical Studies}

\section{TRIPs Agreement as International Framework for Intellectual Property Rights Including Patent}

TRIPs as the international framework for intellectual property rights have important implication for public health. The TRIPs Agreement sets out detailed obligations in respect of the protection of inventions, including: (Correa $\mathrm{C}$ and A. Yusuf, 1998)

- To recognize patents for inventions in all fields of technology, with limited exceptions;

- Not to discriminate with respect to the availability or enjoyment of patent rights;

- To grant patent rights for at least twenty years from the date of application;

- To limit the scope of exceptions to patent rights and to grant compulsory licenses only under certain conditions;

- To effectively enforce patent rights; 
Patents granted monopoly rights for the holder parallel with massive monetary benefit, especially for pharmaceutical companies when they are able to maximize the biodiversity existed in nature into a useful product, for example medicines. With some $80 \%$ of the world's biological diversity lying in the tropical and sub tropical regions of the south (Velasquez G. and Boulet P, 1999), accompanied by the fact that $56 \%$ of the top 150 prescribed drugs in the United State of America are based on chemicals derived from plants (Inter Press Service, 1998), and the existence of a world market for herbal medicine estimated at USD 43 billion with annual growth rate in between $5 \%$ to $15 \%$ (The Inter - Regional Workshop on Intellectual Property Rights, 2000). Pharmaceutical Industries considered as the most beneficial party of biodiversity based- medicine patent and developing countries, on contrary are the exploited parties who suffered the most of this biodiversity based patent monopoly.

Many developing countries are the "Garden of Eden" of the pharmaceutical industries and their quest for new medicine material in order to gain economic benefit. Genes and gene-related molecules with more than 20.000 having been registered at the US Patent and Trademark Office (USPTO) since 1980 (Gary Stix, 2002) Between 1990 and 1995 around 25.000 biotechnological patents were granted worldwide, representing $1 \%$ of the total number of global patents, $37 \%$ of such patents originates from the US, another $37 \%$ were from Japan, with European Union granted a total of $19 \%$. With the exception of Australia, Canada, China, Israel and Republic of Korea, the rest of the world accounted for a mere $0,7 \%$ of total biotechnological patents (Carlos M. Correa, 2000). Such statistic underline the value of such resources and are also indicative of a huge imbalance in the number of patent issued in the North and South explaining the reinforcement of Northern commercial domination through Patent, which favors a worldwide high - level and non-discriminatory patent system reflecting the policy agenda of Western technology exporters. Developing countries have been the primary sources of bioprospection to obtain new material for medicines, and after the medicines are patented, developing countries become very potential markets for pharmaceutical industries and in many cases, those medicines are unaffordable by most of society in developing countries, this is a cruel irony considering the pharmaceutical took materials from developing countries, filling patented medicines for law protection in developing countries and sold back to them in order to gain massive monetary benefit.

\section{Public Health Concerns and the Role of Patents}

The perspective of public health focuses on issue relating to access to medicines. The protection of public health is one of the most pressing issues in developing countries because a large part of the world population still lacks access to essential drugs. Evidence that correlates poverty with high disease burden is compelling, because poverty affects purchasing power. Today, $58 \%$ of malaria cases occur in the poorest $20 \%$ of the world's population, a greater proportion of any of any other disease of major public health importance in developing countries and among poor people, the hardest hit by far is sick children and pregnant women. (McCarthy, FD, et al, 2000) and $82 \%$ of rotavirus diarrhea death occur in the world's poorest countries (Bresee JS, et al, 2003). The African continent is home to $90 \%$ of the malaria burden and the overwhelming majority of malaria related death. (WHO, 2006).

\section{Ground for Granting Compulsory License as Fair and Equitable Benefit Sharing for Biodiversity - Based Patent Medicines Consider Public Health}

Compulsory license is the authorization given by a judicial or administrative authority to a third party for the use of a patented invention, without the consent of the patentee or various grounds of general interest (absence of working, public health, anticompetitive practices, emergency, national defense) (Lehter, 1995). The provision of compulsory license is a crucial element in public health-related patent law, but the use of such license has been generally opposed by the research-based pharmaceutical industry (Bond, 1999) on the ground that they discourage investment, research and development.(Scherer,F.M. (1998). 
Most developed countries provide for use of compulsory licenses, many developing countries that have recently revised their patent laws have also defined a more or less comprehensive list of reasons for the granting of such licenses. (Correa, 2000). Some countries have provided compulsory licenses for specific products, such as pharmaceuticals and food. Canada first introduced compulsory licensing for medicines in 1923, under which compulsory licenses had been granted and a sizeable generic pharmaceutical industry had developed.(Robic, 1990.) French law authorizes compulsory licenses specifically related to medicines. Where the interests of public health demand, and in the absence of a voluntary agreement with the patent holder, the minister responsible for industrial property, may, by order of the minister responsible for public health, request ex officio licenses in accordance with Article L. 613-17 for any patent granted. (Love, 2007). Some laws refer generally to public health, for example Brazilian Decree 3201 / 99 established that in cases of national emergency or public interest declared by Federal Executive Authorities. Public interest defined broadly including public health protection, satisfying nutritional requirements, protection of the environment and other areas of fundamental importance to the technological or social and economic development (Correa, 2000)

\section{Methodology}

This research is preceded by studying and examining the literature on theories and concept related to the theme discussed. The method is qualitative research characterized by its aims, which relate to understanding some aspect of social life in exploring the possibility of implementing automatic compulsory license as the form of fair and equitable benefit sharing for biodiversity based-patent to ensure the security of public health in origin country. This qualitative research also expected to be able to interpret the appropriate legal Ground for Granting Compulsory License based as Fair and Equitable Benefit Sharing for Biodiversity - Based Patent Medicines Consider Public Health Interest and provide recommendations for the better system as the conclusions.

\section{Result of Analysis}

\section{Identification of the Ideal Patent Regulation in Developing Countries}

In designing a national patent system, policy makers should consider many related issue, such as public health, protection of the environment, the promotion of trade competition and technology transfer (Reichman, 1994 and 1997), careful consideration should be given to regulations in patent law system affecting public health such as those relating to the approval and registration of medicines, in order to develop a consistent legal framework that enhances access to required medicines. (Correa, 2000) The thing that should be noticed by developing countries that TRIPs Agreement does not establish unification about international law nor even uniform legal requirements in implementing Intellectual Property Rights including Patent. The only obligation for WTO member states is to comply with minimum standards of intellectual property rights protection according to TRIPs agreement.

There are plenty of chances and considerable room for developing countries as well as other countries to develop their own patent law and other intellectual property laws in response to the characteristic of their legal systems. National patent law should be designed to serve the interest of society and responsive to public health and, in particular to the needs of the poor. Every country may legitimately adopt regulations that ensure a balance between the minimum standards of intellectual property rights protection and the public good (Correa, Carlos, 2000). According to the article 7 of TRIPs Agreement The protection and enforcement of intellectual property rights should contribute to the promotion of technological innovation and to the transfer and dissemination of technology, to the mutual advantage of producers and users of technological knowledge and in a manner conducive to social and economic welfare, and to a balance of rights and obligations. There are strong pressures about mutual advantage, social and economic welfare and the balance of rights and obligation. National legal patent should be concentrates on provision and mechanism in patent laws that may increase the affordability of medicines, including diagnostics, preventive and curative medicines. 


\section{Identification of the possibility of implementing automatic compulsory license as the form of fair and equitable benefit sharing}

Bio-prospecting is an important potential source of novel chemical and biological products for medicine, agriculture, and other industries. But a great deal of the world's "biodiversity" is found in developing countries, this is the main reason why developing countries whose provide an area for biodiversity prospecting and biological products should receive a share of the benefits from biodiversity based patents. In accordance to patent and public health, developing countries should treat specific patent issues for example exceptions to exclusive rights. The World Health Organization has recommended the use of compulsory licenses where there is "abuse of patent rights or a national emergency" in order to ensure that drug prices are consistent with local purchasing power (Correa, Carlos M, 2000). A public health sensitive approach should not only aim to address short - term emergencies that could justify several sorts of temporary measures such as for the supply of medicines in cases of epidemic, catastrophe or national health emergency, but should be devised as part of an integrated medium or long term national patent policy and strategy. Despite the provisions for compulsory licenses in many national laws relatively few compulsory licenses have actually been granted.

Article 31 of The TRIPs agreement specifically allows Member States to grant compulsory licenses on grounds to be determined by each member states but does not restrict the possible grounds to those actually cited. A health - sensitive patent law may specifically provide for several grounds for compulsory licenses, notably:

- Emergency : such as when urgent public health needs exist as a result of a natural catastrophe, war or epidemic

- Anticompetitive practices : for instance, to correct excessive prices and other abusive practices

- Governmental use : such as to provide health care to the poor

- Public interest: broadly defined to cover other situations where the public interest is involved (this in fact, the practice in the USA, where government may use patents without a license.

Due to its significance and sensitive aspect, compulsory license for biodiversity based medicines patent in developing countries should be the requirement in the first place when pharmaceutical industries are intend to conduct bioprospecting (seeking beneficial materials for medicines creation), the requirement can be formulated in certain ways for example:

1. Documents should be precisely clear about origin or source of genetic resources and associated traditional knowledge used in patent process.

2. The making of agreement like Material Transfer Agreement used as the basis of any agreement regarding biological resources taken from the country of origin

3. Creation of Bioprospecting, Access and Benefit Sharing. BABS Regulations to propose a model prior informed consent agreement, a model transfer material agreement, a model benefit-sharing agreement and a model information-sharing agreement.

4. Mutually agreed term that compulsory license will be granted automatically for the origin country of biodiversity-based medicine patent as the fair share for its genetic resources and traditional knowledge used in medicine making process.

\section{Conclusion}

The developing countries should be aware that considering the national public health factor, the most useful form of benefit sharing is compulsory license or the agreement that government may use the biodiversity-based medicines patent deriving from natural resources for securing national public health and access to medicine for the citizen. This method of benefit sharing has a better possibility to ensure the availability of the medicines and to maintain the prices affordable by society's purchasing power. Compulsory licenses for the country of origin should be automatically granted parallel with patent protection considering the public health and public interest, 
and do not required certain condition like public health emergency, epidemic cases of diseases or catastrophe. The availability of medicines in country of origin should not only about curative medicines but also diagnostics and preventive medicines.

The rights of developing countries to conduct compulsory license for biodiversity based medicine patent should be agreed as the prior requirements in benefit sharing agreement due to the used of biodiversity or natural resources in product making process. TRIPs agreement does not and should not prevent any members from taking measures to protect public health, including compulsory license as one of the flexibilities on patent protection included in the TRIPS Agreement. compulsory license policy should be acknowledge as the rights and duty of the state and project as one of the implementation of fair and equitable benefit sharing in Biodiversity - based Patents.

\section{References}

[1] Bond, Patrick (1999), Globalization, Pharmaceutical Pricing and South African Health Policy: Managing Confrontation with U.S. firms and politicians", International Journal of Health Services, March, 23. https://doi.org/10.2190/4ma6-53e3-le1x-c1yy

[2] Breese JS, et al (2003), "Global Illness and Deaths caused by Rotavirus Disease in Children, Emerging Infectious Disease, 9:565-572. https://doi.org/10.3201/eid0905.020562

[3] Correa, Carlos M., (2000), Intellectual Property Rights, The WTO and Developing Countries (The TRIPs Agreement and Policy Option), Chapter VI, Zed Books.

[4] Correa, Carlos M, (2000), Integrating Public Health Concerns Into Patent Legislation in Developing Countries, University of Buenos Aires, South Centre.

[5] Correa, Carlos M, and A.Yusuf (1998), Intellectual Property and International Trade, The TRIPs Agreement, Kluwer Law International, London-Cambridge

[6] Inter Press Service, “Biopirates Patent Traditional Wisdom”, 8 October 1998, http://www.ips.org.

[7] Love, James Packard (2007) "Recent examples of the use of compulsory licenses on patents ",Knowledge Ecology International 8 March 2007, revised 31 March 2007, http://www.keionline.org/misc-docs/recent_cls_8mar07.pdf

[8] McCarthyFD, et al (2000), Malaria and Growth, Washington, World Bank, Working Paper Number 2303.

[9] Reichman, J (1994), "Legal Hybrids Between the Patent and Copyright Paradigms",94 Columbia Law Review,2432,2448-2453. https://doi.org/10.2307/1123143

[10] Reichman, J (1997), “From Free Riders to Fair Followers: Global Competition under the TRIPs Agreement” New York University, Journal of International Law and Politics, Vol.29, No.1-2.

[11] Robic, Richard Leger, (1990) “ The New Canadian Pharmaceutical Compulsory Licensing Provisions or How to Jump Out of The Frying Pan and Into The Fire"Centre CDP Capital, Montreal, Quebec, Canada, http://www.robic.ca/admin/pdf/514/167E-TO.pdf.

[12] Scherer,F.M. (1998), Comments in Anderson, Robert\& Gallini, Nancy (eds) Competition Policy and Intellectual Property Rights in The Knowledge based Economy, University of Calgary Pres,Alberta.

[13] Stix, Gary (2002) "Legal Circumvention: Molecular Switches Provide a Route Around Existing Gene Patents", Scientific American. https://doi.org/10.1038/scientificamerican0702-36

[14]The Inter - Regional Workshop on Intellectual Property Rights in The Context of Traditional Medicine, Bangkok, 6-8 December 2000

[15] Vaver, David (1997) “Intellectual Property Law, Copyright,Patents, Trade Marks”, Irwin Law, Concord,Ontario.

[16] Velasquez G. and Boulet P (1999) "Essential Drugs in The New Internationl Environment" Bulletin of The World Health Organisation, 77 (3)

[17] WIPO Intellectual Property Handbook: (2008) Policy, Law and Use. Chapter 2: Fields of Intellectual Property Protection WIPO

[18] World Health Organization Library, (2006), Public Health Innovation and Intellectual Property Rights, Report of The Commission on Intellectual Property Rights Innovation and Public Health. 